Vaneasa Online Journal

$1.2 \mid 2013$

Varia

\title{
Kolam patterns as materialisation and embodiment of rhythms
}

Anna Laine

\section{(2) OpenEdition}

1 Journals

\section{Electronic version}

URL: http://journals.openedition.org/anthrovision/607

DOI: 10.4000/anthrovision.607

ISSN: 2198-6754

\section{Publisher}

VANEASA - Visual Anthropology Network of European Association of Social Anthropologists

\section{Electronic reference}

Anna Laine, "Kolam patterns as materialisation and embodiment of rhythms », Anthrovision [Online], 1.2 | 2013, Online since 05 August 2013, connection on 19 April 2019. URL : http:// journals.openedition.org/anthrovision/607; DOI : 10.4000/anthrovision.607

This text was automatically generated on 19 April 2019

(C) Anthrovision 


\section{Kolam patterns as materialisation and embodiment of rhythms}

\section{Anna Laine}

Friday morning kolam in Thiruvannamalai district, Tamil Nadu

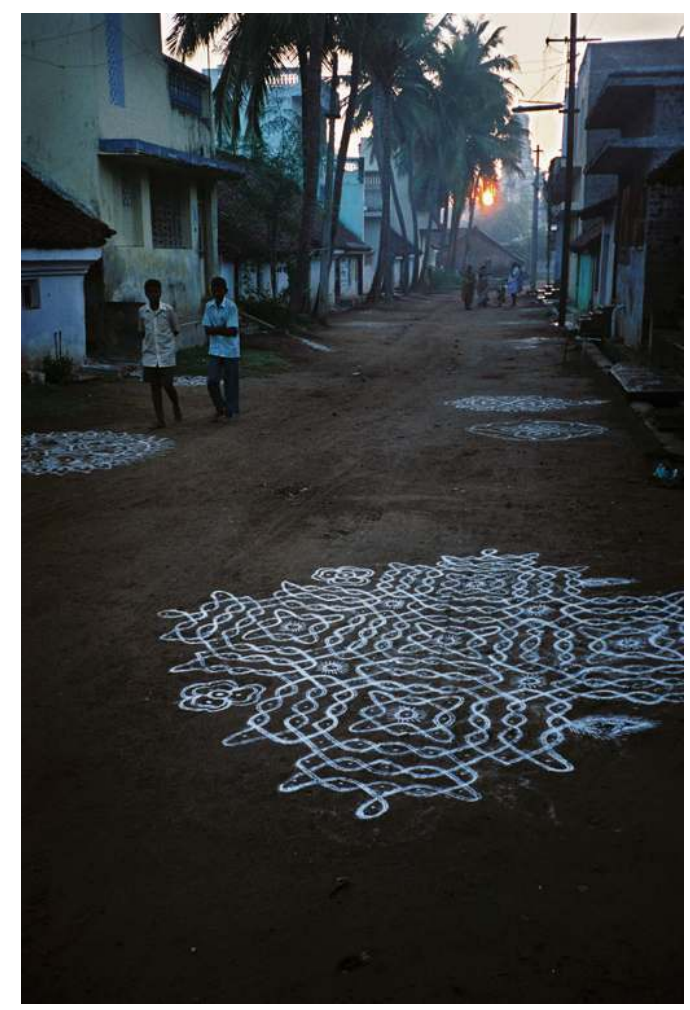

Photo by the author

Henri Lefebvre suggests the analysis of rhythms as a particular field of knowledge. In his conceptualisation, rhythm is the interaction between time, space and energy in processes of everyday life (Lefebvre 2004: 15). We lead our lives in polyrhythmic fields where 
different rhythms simultaneously are flowing into and out of each other. Some flows can be defined as physical, others social, where the latter often conditions the former, such as how we walk or when we eat. Rhythm is inseparable from understanding time, and in particular reiteration. But a rhythm is not a series of identical facts or a mechanical repetition. There is always something new that introduces itself when a movement is reenacted, every act holds difference and contingency. In a rhythm analysis, we need to investigate and define the multitude of rhythms we are surrounded by, how they are related, what unifies them, what causes alterity in the repetitions, and what disrupts a certain rhythm.

2 Lefebvre's theory of rhythm is situated within experiential knowledge. He criticises the neglect of the body in philosophy and argues that we need to begin in our own experiences to understand how rhythm can be useful as a form of analysis (Lefebvre 2004: 21). We should put ourselves in a rhythmical mode, and use our own bodily rhythms as referents in order to subsequently comprehend external rhythms and their relations in an open-ended whole. Lefebvre contends that 'to grasp a rhythm it is necessary to have been grasped by it; one must let oneself go' (Lefebvre 2004: 27). This emphasis on reciprocity and close engagement in the encounter resonates with how my understanding of the kolam practice evolved during fieldwork. I did not pay attention to the rhythmical aspects of the practice until I had begun to learn how to make the patterns and hereby incorporated a rhythm of drawing. Similar to Lefebvre's suggestions, I explored my internal rhythms and their reconfiguration during fieldwork, and used them as points of references in the analysis of external socio-religious rhythms in the context of the kolam practice.

3 Being an image-maker as much as an anthropologist, tactile interaction with materials in self-reflexive processes of "thinking through making" (Ravetz 2011), constitutes an important element of my research as well as of how it is conveyed. Images and films can evoke tactile experiences and sensory details in a way that is difficult to accomplish through ethnographic texts (MacDougall 1997). This article argues that the rhythmical aspects of the kolam practice, which concern its multifaceted relations to extra-ordinary events, daily life and embodied skills, need to be presented through sound and moving images in order to be grasped by non-practitioners. The argument is concerned with epistemological inquiries into how anthropological knowledge can be formed and conveyed through practice-based methods in relation to textual, and it will therefore be mediated in the following text as well as through a video installation accessible at http:// www.vimeo.com/4290542. ${ }^{1}$ The synesthetic capacity of film is used in the video in order to make the beholder experience the materiality of kolam making as well as the practice's visceral connection to spatiotemporal rhythms. The text represents a wider context concerning enactments of kolam, and situates the practice in Hindu understandings of the energy that moves time and space.

\section{Qualities of Temporal Rhythms}

Every morning and afternoon, kolam patterns are put on the street at the entrances of the majority of houses in Tamilnadu. The images materialise and embody the rhythm of the day. The performance is further organised into a regularity of flows defined by weekly, monthly and annual circumstances related to the rhythm of planets and the following seasons. According to a weekly rhythm, kolam is also made in front of deities, in 
temples as well as at altars in homes and at offices. An intersecting rhythm is defined by life-cycles of individual household members. During auspicious events, such as a marriage or a temple festival, women draw large and intricate kolams. During inauspicious occasions, such as a death in the family, or the monthly commemoration of ancestors, no kolams are made. The presence of big kolams enhances auspiciousness, while their absence causes sadness. They way women draw, or refrain from drawing, kolams has an impact on the mood experienced in the community.

5 Kolam is founded within Hinduism where time itself is defined according to the qualities auspicious and inauspicious. The increased presence of auspiciousness during a certain period is related to particular valuations of the rhythmical movements of the planets. In Hindu life, there are times when certain things should or should not be done. Auspicious events ought to be performed during auspicious periods of time in order to have appositive outcome (cf. Good 1991, Hancock 1999, Fuller 1992, Madan 1985, 1991). Based on the movements of planets and how they influence each other, astrology defines time and its different qualities. Most of the people I engaged with during fieldwork hold that the interaction between the planets influences their everyday lives in many ways, for instance, the risk of being attacked by evil spirits is considered to be larger during inauspicious periods. When people face problems, some take the advice of an astrologer and worship a certain planet as a remedy, while those who are affected by evil spirits may consult a sorcerer. People rarely speak about the latter, but it is openly considered important to confer with an astrologer, particularly when the right marriage partner is to be chosen.

6 The influencing planets are the Navagrahas, whom are regarded as nine gods. With the sun god in the middle, they stand together in a symmetrical form of nine anthropomorphic figures, next to large temples that have other main deities, or in smaller temples of their own. While some women worship the planet gods by drawing particular kolams at their home altars, others walk around them nine times in their sculptural forms in the temples. Sanni, the god of Saturn who governs Saturday, is considered to have an ability to cause bad influences in a person's life during a longer period. It is important to maintain a good relationship with all deities, no less with those of ambivalent character. To keep Sanni pleased, many women feed him cooling rice with sesame seeds in their back yards on Saturdays, which he consumes through his vehicle the crow.

7 Chandran, the moon god who presides over Mondays, plays an important part in defining auspicious and inauspicious time according to a monthly rhythm. Auspiciousness is at its greatest on pournami, the day on which the moon is full. In correspondence with the waning of the moon, the quality of time becomes more inauspicious until it reaches amavasi, no moon's day. This is the time when rituals are performed for ancestors and kolams are absent from the streets. With the waxing of the moon, time again becomes auspicious, and the drawing is resumed.

8 The evaluation of time further interacts with how divine energy influences each weekday's division into good and bad periods. People who belong to the Brahmin caste define the early morning hours when the kolam should be made as Brahma muhurtam, the time when Brahma and all other deities descend to the earth. Other groups refer to benevolence of this period as the time when Surya, the sun god, returns from Yema, god of death, and his realm in the underworld. The unease of darkness is brought to an end through the light generated by the sun god. In the afternoon, a new kolam should be in 
place before the sunsets. Certain hours are defined as nalla kalam, good time. During these hours auspicious functions are held, and jewellery and wedding saris are bought. There are two periods of inauspicious time in a day. One is Ragu kalam, unfavourable time influenced by Ragu, and Yema gandham, highly risky time influenced by Kelu. Ragu and Kelu are nodes of the moon, and they belong to the Navagrahas although they are not connected to particular week days. Yema gandham and Ragu kalam occur when the shadows of Ragu or Kelu fall upon the earth, in its worst form as a solar or lunar eclipse. Several practices prescribe how to avoid bad effects during such occasions, and particularly pregnant women need to take precaution. Additionally, people refer to kuligey kalam, a time of the day when it is bad to die or have funeral functions. People in general do not keep the exact timings in mind on average days, but when for example the time for a wedding is to be set, or a new business to get started, the right day and hours are essential. Calendars, which are commonly kept on the walls in several numbers, contain the precise hours of good and bad times, as well as days for particular festivals and pujas. The calendars, and sometimes an astrologer, are consulted before the time for an important event is set.

\section{Spatial Aspects of the Patterns}

During a dance performance, the artist translates the temporal dimension of music into spatial terms (Barba and Savarese 2006: 246). The kolam maker has a similar capacity, but the spatial terms include the evolvement of an image. The materialisation of the temporal rhythms is generated in the movements of the woman when she draws the image, and becomes manifest in the image when she has completed the pattern. The performance and the symmetrical image it produces (the duration of which varies according to the chosen material) are rhythmical interactions in space. The daily kolam patterns occupy a relatively small space, but the images are usually enlarged on Fridays. The Goddess, to whom most kolams are directed, is considered to be closer and easier to reach on this particular weekday. Before any kolam is made, the surface on which it will be drawn is carefully cleaned. When the patterns are extended, the cleaning is more thorough. The Friday cleaning includes the stove, and a kolam is thus also put there.

The grandest and most intricate kolams are laid out in space according to an annual rhythm. This occurs during the harvest festival, Pongal, which is the most popular celebration in Tamilnadu (cf. Gough 1981). The yielded crops bring abundance, and hope of prosperity is at a peak. The darkest inauspicious period of the year is left behind as the winter solstice has just passed, and all kolams are turned towards Surya. The festival has developed within agricultural practices and is consequently given more importance in rural areas. Pongal is compressed into one day among most city dwellers, but the value of elaborate big kolams transgresses other rural/urban differentiations. Hours instead of minutes are spent on drawing, and on smaller streets there is often only a narrow path in the middle which is not covered by colourful designs. The extended time and space allows for experiments with new materials and compositions. Kolam makers often work together on the same image, which generates a collective creativity, and the large images increase the joyous atmosphere in the community. At the same time, there is an aspect of individuality in kolam making. During Pongal, some women engage in informal competitions where they compare their patterns and make remarks on accomplishments 
and mishaps. It is also popular to participate in publicly organised competitions, where the winner earns a price as well as social prestige.

11 The rhythms of annual, monthly, weekly and daily changes are intersected by a rhythm defined by life-cycles of individual household members. Most of these events, such as the celebration of a girl's first menstruation, marriage, and moving in to a new house, are also auspicious occasions. The kolams that are drawn in celebration of these family functions resemble those made at festivals. But if a death has occurred during Pongal or a temple festival, the household will not participate in the joint event and the entrance is left without a kolam. Thus, the separation between auspiciousness and inauspiciousness might clash in the complexities of everyday life. The kolam firstly communicates the state of being within the home, and secondly on the community level.

The kolam patterns form part of the larger rhythm of a street. In accordance with the temporal rhythms, their size or absence causes changes in the street pattern, which communicate the occurrence of events beyond the ordinary. Perceptions of the variations induce or reinforce the aesthetic experience and emotional state of the people passing by, and sometimes bring on memories of previous events. Through the different ways women enact, or refrain from enacting, the kolam practice, their performances materialise various rhythms of life. The absence of the kolam is the weaker part in the rhythm of life, while the enlarged sizes on auspicious occasions intensify its flow.

\section{Learning Feminine Rhythms}

From a Hindu perspective, the energy that rhythmically moves time and space is divine. The energy is understood as shakti (or prakriti). Shakti is a name of The Goddess, as well as a term that is translated as power. In this context, it is particularly linked to divine female power or energy, and characterised by a capacity to both create and destroy. Male gods depend on shakti in order to act, as the male principle purusha is passive in opposition to the female active principle prakriti (Fuller 1992). All women are considered to embody shakti, and thus share the capacities of The Goddess (Wadley 1991). Through kolam making, women channel the divine energy into social life, and many of them hold that shakti is the source of their skills in kolam making.

Learning to make kolams is a rhythmical mode of becoming a feminine being. Girls develop into womanhood as they participate in kolam drawing, cooking and other female responsibilities. As they accompany elders to the temple and learn how to make puja, they gradually become aware of the religious implications of kolam. The refinement of their skills is closely connected to their capacity to become good wives and mothers. According to Jean Lave and Etienne Wenger, 'learning is not one practice among others, but an inseparable part of all social practice' (Lave and Wenger 2003: 34). They argue that learning takes place where participants are actively engaged in communities of practice. Reflection and involvement, or cerebral and embodied learning, interact in the process, which gradually proceeds as a cyclic movement from periphery to centre. Apprentices become involved through the enactment of simpler tasks, and when the master decides, it is possible to be given more central responsibilities. In the same sense, girls do not start immediately with the morning kolam, but move slowly from practicing in notebooks and on the smaller afternoon kolams. During the enactment, rhythms inherent in the body of the individual performer, such as breathing, interact with the socially learned rhythms of drawing. 

drawing as an adult. She learned to make simple kolams as a child, but soon left the practice behind as she opted for studies and her parents were able to send her to higher education which resulted in an academic career outside Tamilnadu. Her decision to recommence the practice was motivated by an aim to re-establish the connection with a deceased aunt, rather than a search for Tamilness or religiousness. Instead of buying magazines with designs to learn from, she searched her relatives' houses to find the ones she remembered that her aunt used to draw on the back of calendars. Some were found, and while using them as models, the woman contends that her body recalls the rhythm of drawing from her childhood. At the time of my study, her practice was mainly something private, in a state of rehearsal inside the home. The only time she had made a kolam outside was when her brother came to visit with his family from the USA, and she felt this was the best way to welcome them. Others have related kolam rhythms to music and dancing, and used the practice as a pedagogical tool for children with reading disabilities. Kolam workshops have also been used by companies to reduce the stress level at their offices, and some argue that its rhythmical performance is a type of yoga that reconnects mind and body as well as constitute physical exercise. example rhythm people through military training in order to strengthen or re-establish eurhythmia, balance and order, and avoid arrhythmia, conflict (Lefebvre 2004: 68). The learning of the kolam practice can, in a similar way, be understood as a means to strengthen a balanced state between a multiplicity of rhythms, to uphold a gendered continuity and circumvent its disruption. Through the repetitive movements women learn, and come to embody, the flow that is their morally correct way to interact with the rhythms of seasons and lives. But repetition entails difference, and each woman develops her own rhythm of drawing. Similar to hand writing, nobody's kolam looks like someone else's. Neither does it look the same from one day to the next. Some women deliberately stretch boundaries, while others mainly conform. As put by Lave and Wenger: "The knowers (full participants) come in a range of types, from clones to heretics' (Lave and Wenger 2003: 116). The authors stress that mutuality between master and apprentice in the constitution of a practice is a central aspect of the learning process. It is not only an apprentice that changes in the process. Although the relationship entails aspects of power, both agents are active learners. The enactments of known routines, improvisations, and shifting meanings, give space for unpredictability as well as changing strategies. The practitioners and the activity are thus mutually constitutive (Lave and Wenger 2003: 33). The kolam practice continuously incorporates new materials and values and they are negotiated within and between the performers as well as in relation to the larger community. Whether a particular kolam maker's view is given prominence depends on that person's skill and social position and may not necessarily intersect with the master/apprentice relation.

\section{Reconfiguring Repeated Movements}

17 While difference and contingency is part of all repetition, the pace through which the kolam rhythms change has increased during the last three decades. One aspect is the interval of making kolam, and the interval of the resulting images. Recent alterations in chosen materials and tools embody shifting meanings developing through the passing of 
time. According to most kolam makers, the ideal material to make the patterns of is rice flour. It is an offering to the deities with hope of abundant return, and it is also given as food for insects and birds. Patterns of this material vanish quickly. On auspicious occasions when much effort is put into kolam making, the rice flour has been mixed with water and the images have lasted longer. While the ideal material is what most people have at hand, the last decades have brought forth new materials and tools that only can be bought. The changes are related to new construction materials of houses and roads, and further connected to an aim towards increased economic standard. Families that can afford to build a new house in concrete can also afford to have outdoor kolams in colour powder or acrylic paint, and indoor kolams in plastic adhesive. It articulates status to make kolams in new materials and forms.

The duration of a kolam in acrylic paint extents to a year, and this type of images constitutes a new rhythm of kolam making. Many have an ambivalent attitude towards the changes, and make daily kolams in addition to the acrylic ones. Those who do not get more time for other chores during the day, and can thus transform their daily rhythms. At the same time, higher education among girls is increasingly important. Their daily practice of kolam making when they come home from school has for many altered into homework and tuition classes. Among the middle and upper classes, women have begun to employ servants to do the daily kolam. The woman of the house might continue to make them on auspicious occasions when more time is given for creativity, or she might stop completely. The disruption of daily rhythms accords with women's increased movements outside the neighbourhood through education and work. The transformations of daily rhythms thus also have spatial implications. Changes in how kolam are made and look materialises the passing of time as well as the changing circumstances and values it entails. The alterations reconfigure the polyrhythmic fields of everyday life.

The changes pose questions of which energy reconfigures the rhythmical movements embodied in kolam. The answer might be found in the working of modernity, with an increased pressure of consumerism and individual accomplishments. Daily watched TV serials for example are imbued with commercials on how to improve one's life through consumption. However, it can also be related to creativity, the energy that lies in the desire to improvise. Elizabeth Hallam and Tim Ingold suggest that creativity should be understood as part of how we engage with traditions in our movements of everyday life, not as individual innovation (Hallam and Ingold 2007). There is always a sense of creative improvisation when we adjust and respond to cultural forms, and this continuous process does not have to be perceived as imitation standing in opposition to the creation of something completely new. Continuity and change are intertwined, also in the kolam rhythm. Every morning it remakes the house into a home, and simultaneously, it provides a space to explore changes. It is an example of how various rhythms are actively reproduced, but also how they can be negotiated and reconfigured into different forms of flow.

The difference generated through repetition can be regarded as both conscious and unconscious in the kolam performance. Every time a woman repeats the act of drawing, she tries to make the design different. But the overall daily practice appears similar from last time. New rhythms are incorporated through the different qualities of the new materials, without causing complete disruption. However, some kolam makers seek to alter the established rhythms of status and belonging, and they have to be cautious of not 
becoming defined as too disruptive. That can bring forth gossip, and may jeopardize the future of oneself and one's children.

The learning process is also subject to change. The apprentice/master relationship situated in communities of practice has an informal character, but the increasing lack of participation in such communities brings forth formal training. Children who focus on studies are sometimes sent to summer courses on Tamil traditions, including the kolam practice. These courses are mainly organised through teaching information and giving instructions. Knowledge on kolam is also proliferated through written texts, TV shows and social media. These media can be understood as limiting due to the lack of dialogue between master and apprentice in their present forms. They do not discuss different ideas as much as present what the authors consider as common knowledge. The knowledge production in these contexts often concerns being taught about kolam, rather than learning the actual practice. In a similar manner, this text provides limited knowledge of the meaning and effect of kolam.

\section{Inclusion of Moving Images and Sound}

22 My understanding of the kolam practice and its particular rhythms developed through multi-sensuous experiences of learning how to draw the images during fieldwork. It was not a conscious plan to learn the practice and subsequently build an analytical argument around the knowledge it produced. The attraction of closer engagement was based in my experiences of being an image-maker. Through previous training and professional work within artistic as well as commercial practices, drawing and camera work remain as familiar means of investigation and social interaction. These practices were as unavoidable during fieldwork as in other circumstances. As such, they became part of my research methods, and they have come to situate my interests in the phenomenologically based approach to anthropology which suggests that our senses should be understood as interrelated, and that sensuous experience of everyday practice is central to the constitution of knowledge (cf. Howes 2003, Ingold 2000, Stoller 1997, Taussig 1993). This approach is further positioned in line with Cristina Grasseni's argument that vision should be understood as a socially situated skill, a capacity learnt in interaction with the other senses and a reflecting mind (Grasseni 2007). The way a person looks is formed through an education of perception in relation to the material environment and communities of practice. The expanding interest in sensory aspects of human experience and knowledge has provided means for anthropology to leave the visualist paradigm behind and approach artistic practices and images from a broader perspective. It shapes the framework for my aim to straddle the role of being both an artist and an anthropologist, and explore how these two fields can interact in order to disseminate anthropological knowledge. It also resonates with Hindu understandings of synaesthesia, where vision is closely connected to tactility (Babb 1981, Eck 1981, Gonda 1969).

Acquiring some skill of kolam making from people I engaged with during fieldwork turned out to be a valuable means of understanding the meaning and effect of the tradition, particularly its relation to rhythms. The emergence of this understanding occurred unexpectedly. As I saw a design in the street that I had been practicing on several times, I perceived an intensified awareness and sensed my rhythm of drawing it. Viewing the patterns generated an impulse to move along the rhythm required to accomplish that particular design. After this occasion, I began to pay attention to 
rhythms of other people's drawing, and to kolam's connection to rhythms of life from a wider perspective. Through bodily and material engagement where I allowed myself to become drawn into the practice, I became grasped by its rhythms and was able to think in new ways. Amanda Ravetz discusses related moments of heightened awareness experienced while drawing and filming, and how they brought her into productive situations of sharing and understanding during fieldwork. Playing around with materials is considered to be a valid research method among artists, as a "thinking through making" and Ravetz suggests that this method and way of knowing also can be useful in anthropology (Ravetz 2011). During a self-reflexive process where I reached an enhanced understanding of the kolam practice, including how my personal experiences were related to the social context being studied, making and thinking was intertwined (cf. Solheim Pedersen 2004). The process of integrating practical and analytical orientations has also been part of a research project focused on exploring new methods in the museum context conducted at The Museum of Ethnography, Stockholm (Laine forthcoming).

The methodological perspective has brought forth a necessity to incorporate imagery and sound in the research presentation. While anthropology emphasizes acquirements of experience-based knowledge during fieldwork, the multisensory mode of the learning process often fades away in representations focused on intellectual knowledge. In an extension of David MacDougall's contention that photography and film provide pathways to the other senses (MacDougall 1997), I argue that the experiential aspects of kolam rhythms can be conveyed more strongly through the video than in this text. The incorporation of the video is based on an epistemologically driven aim to integrate practical and theoretical knowledge. It is further motivated by recent suggestions in anthropology of dialogue and collaboration with artists. According to Arnd Schneider and Chris Wright, such collaboration can increase our understanding of the agency of images and our social interaction with them, as well as instigate new strategies for representation. Through an intensified sensual engagement, the mind of the addressees might be kept more open than through a textual analysis (Schneider and Wright 2006, 2010).

The video investigates rhythms and their repetitions, and the fact that every repetition entails a difference. It explores how visual rhythms can be integrated with and broken up by aural rhythms, and how these movements can evoke spatio-temporal experience. It aims to convey the rhythmical aspects of daily kolam making, through the material and visceral aspects of how I learned about rhythm during fieldwork, as well as by bringing forth sensuous and experiential knowledge within the audience. The rhythmical content tries to engender a sense of being involved in a situated process of learning where preconceived understandings can be de- and reconstructed. In addition to tactile incorporation and enactment of rhythms, the video concerns the concepts rhythm and repetition. Conceptualisations and abstract conclusions of fieldwork experience are forms of knowledge commonly required to be represented as text. Sarah Pink contends that a picture cannot be used to discuss a theoretical argument, but pictures can be informed by such arguments (Pink 2006). Relying on practices within conceptual art that explore how ideas can be mediated through art works, this audiovisual piece also poses questions concerning the relevance of incorporating abstract imagery in anthropological representations. If we take the capacity of images and films to convey immediate experience as well as to represent analytical reflection into account, we can investigate 
how the shifting meanings of this media come about and consequently make it more beneficial for sharing anthropological knowledge.

\section{BIBLIOGRAPHY}

Babb, Lawrence, 1981. "Glancing: Visual Interaction in Hinduism”, in Journal of Anthropological Research, vol.37, no.4, p.387-401.

Barba, Eugenio and Savarese, Nicola, 2006 [1991]. A Dictionary of Theatre Anthropology: The Secret Art of the Performer, London and New York: Routledge.

Eck, Diana, 1981. Darshan: Seeing the Divine Image in India, Pennsylvania: Anima Books.

Fuller, Christopher J., 1992. The Camphor Flame: Popular Hinduism and Society in India, Princeton: Princeton University Press.

Gonda, Jan, 1969. Eye and Gaze in the Veda, Amsterdam and London: North-Holland Publishing Company.

Good, Anthony, 1991. The Female Bridegroom: A Comparative Study of Life-Crisis Rituals in South India and Sri Lanka, Oxford: Clarendon Press.

Gough, Kathleen, 1981. Rural Society in Southeast India, Cambridge and London: Cambridge University Press.

Grasseni, Cristina, ed. 2007. Skilled Visions: Between Apprenticeship and Standards, New York and Oxford: Berghahn Books.

Hallam, Elizabeth and Ingold, Tim, 2007. Creativity and Cultural Improvisation, Oxford and New York: Berg.

Hancock, Mary, 1999. Womanhood in the Making: Domestic Ritual and Public Culture in Urban South India, Boulder, Colorado: Westview Press.

Howes, David, 2003. Sensual Relations: Engaging the Senses in Culture and Social Theory, Michigan: University of Michigan press.

Ingold, Tim, 2000. The Perception of the Environment: Essays in Livelihood, Dwelling and Skill, New York: Routledge.

Laine, Anna, 2009. In Conversation with the Kolam Practice: Auspiciousness and Artistic Experiences among Women of Tamilnadu, South India. PhD thesis, University of Gothenburg, http:// hdl.handle.net/2077/19290.

Forthcoming: Looking and Drawing: Explorations into an Ethnographically Collected South Indian Object, The Museum of Ethnography, Open Access.

Lave, Jean and Wenger, Etienne, 2003 [1991]. Situated Learning: Legitimate Peripheral Participation, Cambridge: Cambridge University Press.

Lefebvre, Henri, 2004. Rhythmanalysis: Space, Time and Everyday Life, London and New York: Continuum. 
MacDougall, David, 1997. "The Visual in Anthropology”, in Rethinking Visual Anthropology, ed. M. Banks and H. Morphy, New Haven and London: Yale University Press.

Madan, T.N., 1985. "Concerning the Categories Subha and Suddha in Hindu Culture: An Exploratory Essay", in Purity and Auspiciousness in Indian Society, ed. Carman and Marglin, Leiden: E.J. Brill.

1991. “Auspiciousness and purity: Some reconsiderations", in Contributions to Indian Sociology, vol.25, no.2, p.287-294. New Delhi and London: Sage.

Pink, Sarah, 2006. The Future of Visual Anthropology: Engaging the Senses, London and New York: Routledge.

Ravetz, Amanda, 2011. “'Both Created and Discovered': A Case for Reverie and Play in a Redrawn Anthropology", in Redrawing Anthropology: Materials, Movements and Lines, ed. T. Ingold, Farnham and Burlington: Ashgate.

Schneider, Arnd, and Wright, Chris, ed., 2006. Contemporary Art and Anthropology, Oxford and New York: Berg.

2010. Between Art and Anthropology: Contemporary Ethnographic Practice, Oxford and New York: Berg Publ.

Solheim Pedersen, Eirin Marie, 2004. Om teckning, tecken, text och teori: aktteckning i ett kontextuellt, diskursivt och paradigmatiskt perspektiv, Oslo: Arkitekthögskolan, $\mathrm{PhD}$ dissertation in artistic research.

Stoller, Paul, 1997. Sensuous Scholarship, Philadelphia: University of Pennsylvania Press.

Taussig, Michael, 1993. Mimesis and Alterity: A Particular History of the Senses, New York and London: Routledge.

Wadley, Susan, ed., 1991 [1980]. The Powers of Tamil Women, New York: Maxwell School of Citizenship and Public Affairs.

\section{NOTES}

1. The video is seven minutes long, and has been constructed as a loop rather than a linear narrative. I initially created it as part an exhibition made in collaboration with a Tamil and a Swedish artist, presented in an art gallery situated in an upper middle class area in New Delh (2009). After this event, it has become part of my individual exhibition on the kolam practice, Kolam - Ephemeral Patterns of Eternal Prosperity, shown at Brunei Gallery, SOAS, London, The Ethnographic Museum, Stockholm, and The Blue Place Cultural Centre, Gothenburg. In addition, the piece has been part of conference presentations at EASA, Maynooth University, SANT, Gothenburg University, and Transcultural Cinema, Aarhus University. 


\section{ABSTRACTS}

This presentation aims to convey a notion of time that is concerned with the making and using of material objects in everyday life. This will be done through the concept rhythm, as defined by Henri Lefebvre, and as experienced during my fieldwork. The ethnographic example is the kolam, a practice and image that forms part of daily life in Tamilnadu, a state in South India. Kolam is an example of how various rhythms are actively reproduced, but also how they can be negotiated and reconfigured into different forms of flow. The presentation consists of this paper and an accompanying video.

Cet article vise à transmettre la notion de temps, impliqué dans la fabrication et l'utilisation d'objets matériels de la vie quotidienne. Nous développerons cette démonstration en nous appuyant sur le concept de rythme comme a pu le définir Henri Lefebvre, et comme nous en avons fait l'expérience durant notre travail de terrain. Nous partons de l'exemple ethnographique le kolam, une pratique et une image qui constituent une partie de la vie quotidienne du Talminadu, un état de l'Inde du sud. Kolam est un exemple de la manière dont plusieurs rythmes peuvent être reproduits mais aussi négociés et reconstruits sous différentes modalités. Cette présentation est composée de cet article et d'une vidéo.

El objetivo de esta presentación es transmitir una noción de tiempo vinculada a la fabricación y el uso de objetos materiales en la vida cotidiana. Para llevar a cabo dicho objetivo me basaré en el concepto de ritmo, según la definición de Henri Lefebvre, y en mi experiencia de trabajo de campo. El ejemplo etnográfico que se tomará en cuenta es el kolam, una práctica y una imagen que forman parte del día a día de Tamilnadu, un estado del sur de India. Kolam es un ejemplo de cómo diferentes ritmos son reproducidos activamente, pero también de cómo éstos ritmos pueden ser negociados y reconfigurados en diferentes modalidades. La presentación consiste en este artículo y en un vídeo que lo acompaña.

\section{INDEX}

Keywords: rhythm, movements, time-space, hinduism, South India, sensuous anthropology, experience-based knowledge, audiovisual representation

Palabras claves: ritmo, movimientos, tiempo-espacio, hinduismo, India del Sur, antropología de los sentidos, conocimiento basado en la práctica, representación

Mots-clés: rythme, mouvements, espace-temps, hindouisme, Inde du Sud, anthropologie des sens, savoir fondé sur la pratique, représentation audiovisuelle

\section{AUTHOR}

\section{ANNA LAINE}

Dalarna University, Sweden, Senior lecturer in anthropology at Dalarna University, Sweden. She works within the overlap between art and anthropology, and is trained as a photographer as well 
as an academic scholar. Laine has done research on the kolam practice in South India, and currently focuses on visual aspects of identity among the Tamil diaspora in London. She is also involved in a research project on methodology and sacred matters at the Ethnography Museum in Stockholm. 